\title{
Political Islam: The shrinking trend and the future trajectory of Islamic political parties in Indonesia
}

\author{
Politik Islam: Tren menurun dan masa depan \\ partai politik Islam di Indonesia
}

\author{
Ahmad Khoirul Umam ${ }^{1} \& \underline{\text { Akhmad Arif Junaidi }}{ }^{2}$ \\ ${ }^{1}$ Faculty of Social and Behavioral Sciences, The University of Queensland, Australia \\ ${ }^{2}$ Faculty of Sharia and Law, State Islamic University (UIN) Walisongo, Semarang \\ Jalan Walisongo No. 3-5, Tambakaji, Ngaliyan, Kota Semarang, Jawa Tengah \\ Telepon: (024) 7604554 \\ E-mail: arif_junaidi2003@yahoo.com
}

\begin{abstract}
The trend of religious conservatism in Indonesian public sector is increasing nowadays. But the trend is not followed by the rise of political Islam's popularity. The Islamic political parties are precisely abandoned by their sympathizers because of some reasons. This paper tries to elaborate the reasons causing the erosion of Islamic parties' political legitimacy. Some fundamental problems such as inability to transform ideology into political platform, internal-factionalism, as well as the crisis of identity will be explained further. The experience from 2009 election can be used to revitalize their power and capacity for the better electability in the next 2014 election. But they seem to be unable to deal with the previous problems making the electability erosion in 2014 more potential and inevitable. Various strategies must be conducted by the parties such as consolidation, revitalizing their political communication strategy, widening political networks across various ideological and religious streams, and others. Without that, their existence would be subordinated by the secular parties to become the second class political players in this biggest Moslem country in the world.
\end{abstract}

Keywords: democracy, Islam, political parties, election, electability, Indonesia

\begin{abstract}
Abstrak
Fenomena konservatisme agama di Indonesia di sektor publik terus tumbuh. Namun tren ini tidak diikuti oleh naiknya popularitas politik Islam. Partai politik Islam seringkali ditinggalkan oleh simpatisannya karena beberapa alasan. Artikel ini mengelaborasi alasan yang menyebabkan erosi dalam legitimasi partai politik Islam. Beberapa alasan yang fundamental adalah ketidakmampuan dalam merubah ideologi dalam platform politik, pengelompokan internal, serta krisis identitas yang akan dijelaskan lebih lanjut. Pengalaman dari pemilihan umum 2009 dapat digunakan untuk merevitalisasi kekuasaan dan kapasitas mereka dalam pemilu 2014. Mereka nampak tidak mampu menyelesaikan persoalan-persoalan yang sebelumnya pernah terjadi yang dapat menurunkan elektabilitas pada pemilu 2014. Berbagai strategi harus diterapkan partai politik seperti melakukan konsolidasi, revitalisasi strategi komunikasi politik, memperluas jaringan politik lintas ideology dan aliran politik. Tanpa hal-hal tersebut, eksistensi partai politik Islam akan tersubordinasi oleh partai sekuler dan menjadi pemain politik kelas kedua di Negara Muslim terbesar di dunia.
\end{abstract}

Kata-kata kunci: demokrasi, Islam, partai politik, pemilihan umum, elektabilitas, Indonesia

\section{Introduction}

The 2014 general election might become the worst for Islamic political parties' electoral outcomes since the fall of New Order regime in 1998. After suffering a dramatic erosion of electability in the previous 2009 election, the Islamic political parties seems remain unable to secure their significant voting appeals towards the next two years election. Public surveys conducted by several agencies during 2012 have painted a gloomy picture for the Islamic-based political parties in which none of them being predicted to remain among the top five parties in 2014 election. The current situation shows a contradictory trend appearing in the recent Indonesian society. While the pattern of Islamization and religious conservatism movements significantly increase, the established Islamic 
political parties are massively abandoned by their sympathizers and supporters implicating the serious declines of electoral result.

In the survey conducted in October 2012, the Indonesian Survey Circle (LSI) found the major Islamic political parties such as the Prosperous Justice Party (PKS), the National Awakening Party (PKB), the National Mandate Party (PAN), the United Development Party (PPP), and others would get less than 5 percent of the vote each and collectively would only gain 21.1 percent of the popular vote (Tempo 15 October 2012). Conducted in 1-8 October 2012 by using 1,200 respondents with the simple question "if the general election were to take place today, to what political party will you deliver your vote?", The survey indicated that secular parties are getting stronger where Golkar would likely win with 21 persent, followed by the Indonesian Democratic Party of Struggle (PDI-P) with 17.2 percent, while the current ruling party namely Democrat Party would decline with 14 percent, and the Great Indonesia Movement (Gerindra) Party and the 'new comer' National Democratic Party (NasDem) would come in the fourth and fifth with 5.2 percent and 5 percent votes.

The similar result of survey found by The Saiful Mujani Research \& Consulting (SMRC) re-asserted the previous polls in which Islam-based political parties are trapped in the crossroads. The survey conducted in the middle of September 2012 also found the three Islamic parties which became the middle class political parties namely PKS, PKB, PPP, and PAN would just get 2 until 3 percent of votes. This agency also predicted Golkar would win the public confidence with 14 percent (Kompas 14 October 2012).

Another survey conducted by the National Survey Institute (LSN) in June 2012 also stated that the overall electability for Islamic political parties was just 15.7 percent, dramatically eroded from 29.14 percent in the 2009 election and 38.39 percent in the 2004 election (The Jakarta Post 2 August 2012). LSN also noted that the public's political behaviour tends to be strongly attracted by secular parties. People's political perspective is perceived to be more inclusive, tolerant, moderate, wellunderstanding the concept of separation of religion from politics, and also ignoring sectarian political practices. The last but not least, opinion poll conducting by research department of Kompas daily, the most reputable newspaper in the country, also described the tragic degradation of Islamic parties' electability. The polling which was conducted in July 2012 found that PKS, as the biggest Islamic political party in 2009 election, just supported by 3 percent of vote, followed by PPP and PAN with 1 percent, meanwhile PKB crowned as the worst with 0.4 percent political support only (Kompas 26 August 2012).

All survey and opinion polls above become a scientific judgment to the declining trend of Islamic political parties' popularity within the biggest Moslem country in the world. When the Islamic parties always claimed to represent the Moslem interest and promoting Islamic ways as the solution for the state's never ending problems such as poverty and corruption, the people become disappointed due to a distrust of pragmatic and opportunistic Islamic political parties. In anticipating before sinking in the political sphere, the Islamic parties indeed transform themselves into open-based political parties, using the religion just as symbol and betraying the swear to include the Islamic principles in their strategic policies.

The pivotal question emerged; why the trend consistently continues from election to election since the reform era? Why the Moslems tend to deliver their sympathy to the secular parties while the Islamic political parties are massively abandoned by the more Islamic conservative society? First of all, attention is going to be focused on the explanation of shrinking trend of Islamic parties' political electability, then followed by the elaboration of 2009 election experience. Furthermore, this article will explain the causes of the electability shrinking trend as the lessons towards 2014 election. 


\section{The triumph of secular parties: A lesson from 2009 election}

Religion has been one of the political elements constituting a fundamental source of power (Mann 1986:22-28). Religion is also convinced to be consistently relevant and significant for every political development as a uniform and shared objective sense of identity including for modern nation-states (Anderson 1983, Gellner 1983). As one of the political instruments, religious values can be concreted as an ideological framework empowering people to cope social circumstances by engaging strategically meaningful actions (Arakaki 2009:80). In Indonesian political context, Islam has played crucial role particularly after reconsolidating itself in the social and political life of the country from years of marginalization under Soeharto's regime conducting a number of approaches such as cooptation, intimidation, fraud, deceit, coercion, and repression to the Islamic elements (Effendy 1998:111, Maarif 1988, Boland 1971, Crouch 1978, Ward 1970, Samson 1978).

The mushrooming Islamic political parties in a newly democratic Indonesia are actually related to the public disappointment with the failure of good governance during the New Order era. The parties were aimed to restore Islam to be original political forces unpolluted by secular methods for governance. They tried to prove the purity of Islam as an ideology to become an efficacious prescription for building the better Islamic society. Despite the religion still plays a big role in politics, Indonesian Moslem support is dropping gradually.

In 2009 election, the Islamic parties' popularity shrinking trend was a sign of public disappointment emerging swing voters and civic disengagement phenomenon in which the civic trust and interpersonal trust to the Islamic political parties are both at disturbingly low ebb. Distrust of Islamic parties has made the supporters' enthusiasm dwindled and the cynicism growing. That is a consequence of the progressive political education resulting rational and smart voters, since, the massdirect democracy has behavioral and attitudinal effects on citizens such as increasing political efficacy and engagement with rational politics (Mendelsohn \& Cutler 2000, Bowler \& Donovan 2002, Smith 2002, Benz \& Stutzer 2004, Lassen 2005).

There were at least ten Islamic parties of 38 political parties totally competing in the 2009 election, either formally using Islam as ideology such as PKS, PPP, PBB, PKNU, and others or the Islamic nationalist parties using Pancasila as the ideology and relying on the Islamic organization to gain supporters such as PKB, PAN, PMB, and others. The 2009 election's final result shows the ten Islamic parties just gained approximately 29 percent of the totally national vote, significantly decrease from 38 percent in 2004 and 37 percent in 1999. It was caused by the established parties' political defeats such as the United Development Party (PPP) reaching 5.2 percent of the vote, while the National Awakening Party (PKB) gained similar number of 5.2 percent also, and the National Mandate Party (PAN) with 6.3 percent.

Meanwhile, the progress had been achieved by the Prosperous Justice Party (PKS) only, gaining 8.2 percent of the vote, a slight increase comparing with 2004 election result with 7.34 percent. But that was actually a relatively stagnant achievement after its seriously loud campaigns and the massive political marketing targeting 20 percent of the votes in 2009. PKS seems to reach its saturation point loosing its spirit to keep up its momentum after a 600 percent vote jumping in 2004 election. Tragically, six of the ten Islamic parties faced considerable electoral defeats since they could not pass 2.5 percent votes of the parliamentary threshold rule, such as the Ulema National Awakening Party (PKNU) with 1.47 percent, the National Sun Party (PMB) with 0.4 percent, PPNUI with 0.14 percent, including the 2004 established parties of the Crescent Star Party (PBB) achieving 1.79 percent only, the Reform Star Party (PBR) obtaining 1.21 percent only.

On the other hand, the nationalist parties show various trends in which Democrat Party impressively reached 20.85 percent of the vote, about 300 percent increase comparing with the 2004 electoral result with 7.5 percent only. The two largest parties, both the Golkar Party and PDIP, dramatically plunged into the second and third level obtaining 14.45 percent and 14.03 percent only, a decrease of 7.3 
percent and 4.5 percent respectively. Meanwhile the two new comer parties both the Great Indonesia Movement Party (Gerindra) and the People's Conscience Party (Hanura) successfully pass the 2.5 percent parliamentary threshold rule by respectively achieving 4.46 percent and 3.77 percent.

In this case, the Islamic parties and other two biggest nationalist pasties' defeats were influenced by the successfully continual political penetrations of Democrat Party (PD) triggering a voter migration phenomenon proven by the PD's political expansion significantly attracting rural voters, either in Java or out of Java's electoral districts, commonly known as the mass base of the Islamic and conservative established nationalist parties.

The defeats of Islamic parties delivered political advantage for nationalist parties particularly Democrat Party (PD), which successfully increased triple votes from 7 percent in 2004 to 20 percent in 2009. Using the political jargon as 'religious-nationalist', PD tried to expand its captive market across socio-political and religious streams. According to the Kompas research, PD had noted an impressive electoral strategy by successfully multiplying its rural voters of the 60 percent total voters reside. About 33.4 percent of 60 percent, rural voters consisting of 134 millions electors credited their political preference to $\mathrm{PD}$, while 26.3 percent of urban voters have supported it (Kompas April 1 2009).

Beside that, the multiplying rural voters not only happened in Java, but also spread across nonJavanese voters. The trend is significantly different comparing with 2004 election result in which PD's supporters were dominated by educated Javanese urban voters (17.1 percent) while its rural supporters was only 5.7 percent. According to Indonesian Survey Institute's data, PD has won 14 of 33 provinces defeating the 2004 election winner of Golkar Party winning 11 provinces only in 2009. For example, the electoral outcome of five provinces in Sumatera Island such as Aceh, Sumatera Utara, Sumatera Barat, Bengkulu, and Lampung was totally dominated by PD (22.34 percent), while Riau, Kepulauan Riau (Kepri), Sumatera Selatan, and Bangka Belitung were still won by Golkar Party, and only Jambi province was politically co-opted by PAN (Jawa Pos April 12 2009).

PD's impressive electoral triumph was more clearly gained in Java in which 4 of 5 provinces, excluding Central Java won by PDIP, have become basses of PD's political supporters (21.33 percent). But, in Kalimantan and Sulawesi, PD was not really successful comparing with the provinces above. In Kalimantan, PD just showed its brightness in East Kalimantan, while West and Central Kalimantan were dominated by PDIP, and South Kalimantan was gained by Golkar. The quiet similar trend also happened in Sulawesi in which the superiority of Golkar party still continued. PD just noted its victory in Southeast Sulawesi, while Bali and East Nusa Tenggara were obtained by PDIP and Golkar each.

The incredible vote increase was strongly influenced by Susilo Bambang Yudhoyono's leadership personified as a well-mannered, cautious, and moderate reformist general. The high popularity of SBY was equivalent with PD's electability. SBY had successfully built the political image during his reign period which is also supported by a multi-front campaign team consisted of Echo Team coordinated by the former Indonesian military commander Djoko Suyanto conducting territorial and intelligence operations, Delta Team coordinating logistic support, Bravo Team as the media centre, and Foxtrot Team operating image building strategy (Bapilu Partai Demokrat 2009).

Beside that, the first Yudhoyono cabinet's strategy to rise and the lower fuel price and the reducing fuel subsidy converted into a cash assistance program (Bantuan Langsung Tunai), school operational aid (Bantuan Operasional Sekolah or BOS), a National Independent Civil Empowerment Program (Program Nasional Pemberdayaan Masyarakat Mandiri), easy credit for people (Kredit Usaha Rakyat or KUR), scholarship for poor students, rise for poor people (Beras untuk Rakyat Miskin or Raskin), and public health assistance (Jaminan Kesehatan Masyarakat or Jamkesmas) have positively attracted all social elements from various social background (LSI September 2008). As a result, PD has become a 'catch-all party' accommodating various social elements which are culturally, religiously, and socio-economically different. The situation made constituents disappointed to Islamic 
parties who then turning their heads to SBY and being easily penetrated by PD led to its electoral triumph.

On the other hand, Islamic political parties are lack of leader or icon with brand new ideas, strong and characteristic leadership. As a result, Moslem supports are dropping seriously. What happen in Indonesia and other Moslem countries has been well-diagnosed by Oliver Roy in his magnum opus entitled The Failure of Political Islam (1994) arguing the weakness of political Islam is strongly influenced by at least four major factors. First, there is no clear concept of social, political, and economic circumstances solution. Second, its vague social justice system. Third, factionalism, conflict, and lack of conflict management frequently put them among confrontations significantly absorbing their energy and concentration. Fourth, the loss of religious authenticity. What Roy stated seems to be quite similar with the current trend of Islam politics in Indonesia suffering political defeats due to some reasons bellow.

\section{Swing voters \& inability to transform ideology into political platform}

Elaborating ideology in Indonesian political landscape would be automatically connected to a framework of stream politics based on the religious orientation of santri, abangan, and priyayi which had been one of the main determinant factors in 1955 election (Geertz 1960, Feith 1962, Lev 1967, Liddle 1970, Emmerson 1976, Crouch 1978, Effendy 2003). After neutralized by a long period of political interaction in the New Order era, the trend of political streams (politik aliran) reemerged in 1999 election. Then, Baswedan (2004) compared partisan support in 1999 and 2004 election by using King's methodology (2003) instrumentalizing official election tallies and demographic variables such as indicator of urbanization, government activity, Islamicness, illiteracy, relative inequality and development factor. Baswedan concludes that "at the mass level one still finds stream (aliran) political polarization in 1999. Shifts across streams did not occur in the 2004 election. This finding confirms King's conclusion that stream politics is still influential" (Baswedan 2004:12). Barton (2008) also argued that the voting patterns of election in 1955 and 1999 have scarcely changed at all when it comes to 'syncretism' and 'orthodoxy' sentiment by choosing between Islamic parties and non-Islamic parties.

In the atmosphere of stream politics, Islamic parties strongly considered as the most ideologically minded in determining parties' political strategies and policies. Having Islam as an ideology means every program, activity, and policy must comply with the principle of Islam and utilize religious fundamental values to gain popularity and political support. Islamic ideology had been generally translated by Islamist parties into the political spirit to establish an Islamic state with the formal adoption of Islamic law syari'ah (Elson 2002, Jackson 1980). After a long period of liberal political interaction in the reform era, Islamic parties have been transformed to be pluralistic. They are no longer committed to Islamic law formalization agenda and brought Islam into the foundation of state or constitution, but more focusing on how to deliver Islamic coloration into the state policies. Fealy $(2008,2009)$ argues both parties and voters' supports for pro-syari'ah policies seem to be stagnant and just limited to a very small minority of the Islamic community.

Recently, Indonesian Muslims also tends to be more politically rational, in which their political preferences are no longer determined by religious orientation. That seems to be a significant progress of political education during the reform era. Since, as stated by Smith and Tolbert (2004), "if democratic institutions offer people greater opportunities to participate in decisions, those institutions may have an 'educative' effect on them (Donovan, Tolbert, \& Smith 2009). Then, the educated people tends to be smart, critical, and protest voters politically uncontrolled again by sectarian, primordial, and religious sentiment but reasonably political platform and parties' real programs. The smart voters do not regard religion as pivotal to their electoral preferences, although that may be crucial for their lives. The electorates including the strict or devote Muslims also no longer consider voting as confessional behavior directly correlated to their faith (Fealy 2008, Ricklef 2008). Political fanaticism has declined significantly and electorates tended to be more rational in the sense that ideology and 
primordial factors are no longer important in affecting the voters' political choice. As a result, significant Muslim voters have been swing voters losing faith in the Islamic parties.

The general swing voters tended to be more interested in the economic issue directly connected to their real everyday needs. In the sphere of uncertain and stagnant economic development, welfare has become the main concern among swing voters (Kinder \& Kiewiet 1981). They tended to support parties believed as capable to raise people's welfare. As found by Indonesian Survey Institute's 2008 polling, was asserted the economic issue as the key of electoral sentiment in 2009 (Xinhua 7 February 2008), in which good governance growth, reduction of the unemployment and poverty rates would be the top discourses strongly determining voters' decisions. On the other hand, most parties remain passive with minimum actions to affirm real sector of national economy. The parties politically claimed to represent the lower class by declaring their economic platforms are uniformly protectionist and pro-wong cilik without concrete policies and advocacies, making electors nauseated and despair to the parties which are then labeled as "NATO" (no action talk only). In fact, Islamic political parties did not pay much attention to capitalize upon economic grievances to gain political support, but just more deeply involved into the religious symbolism issues such as legally regionalizing Islamic law (Perda Syari'ah), legalizing law of anti-pornography, supporting anti-Ahmadiyah movements and others.

According to Pepinsky, Liddle, and Mujani's thesis of political Islam's economic advantage (2009), it is concluded that Islamic parties will be more systematically popular than otherwise identical nonIslamic parties only under cases of economic policy uncertainty. When respondents know economic policy platforms, Islamic parties never have an advantage over non-Islamic parties (2009:46). The thesis is proven by the global Islamic political movements occurring in many countries using issue of economic grievances for their political platforms and agendas. For instance, the Pan-Malaysian Islamic Party (PAS) has respectively set up a platform of progressive economic policies and anticorruption (Noor 2003). The Justice and Development Party (AKP) in Turkey used its track record in economic management successfully passing the financial crisis in 2001 (Onis, 2006). In Egypt, the Muslim Brotherhood's growth is influenced by its concern of poverty eradication and economic empowerment based on Islamic ethics (Lia 1998:85-86).

The global phenomenon results a politically strategic message that Islamic parties should have a unique ability and capability to attract sympathizers during the economic circumstances emerges or getting worst or stagnant. In 2004 election, the Prosperous Justice Party (PKS) had successfully capitalized the issue of economic and social justice emphasizing on the idea of economic development and anti-corruption policies based on Islamic values (Hamayotsu 2009). The platform had been concreted by PKS by distributing cheap fertilizer, high quality farm seeds, farming guidance and elucidations, and others. But, after successfully achieved 600 percent increase of political support, the policies have not been followed up properly, even less by other Islamic and Islamic-nationalist parties. As a result, Muslim electorates have shrinking confidence in Islamic political parties' capability to address and overcome socio-economic circumstances.

As the evidence, LSI (2008) conducted survey explaining there is an inverse inclination between parties' Islamic-ness and ability to deliver welfare and prosperity to people. For example; 20 percent of respondents credited PKS as Islamic but only 6 percent perceived it has community welfare programs, while the United Development Party (PPP) is ranked with 15 percent as Islamic but just 2 percent of respondents convincing its contribution into state's economy. Then, for the National Awakening Party (PKB), respondents scored it with 18 percent as 'Islamic' but only 2.5 percent respected its concern on the welfare and prosperity policy. Overall, the big four Islamic parties including the National Mandate Party (PAN) totally achieved 56 percent as Islamic but only 12.5 percent for their community welfare programs. The trend was contrary with secular-nationalist parties comprising Democratic Party, PDIP, Golkar Party, and Gerindra gaining about 43 percent for their concern on prosperity issues (Fealy 2009). So that is why, it is not surprising when Islamic parties experienced an erosion of electability and losing their sympathizers in 2009 election. 


\section{Factionalism, internal conflict and the lack of parties' leadership}

Factionalism in the internal political parties' body is a common phenomenon in the latest government period (2004-2009). Most parties including secular and Islamic parties have experienced internal rifts and schism. The political fragmentations indicate the inability of party elites to manage party homogeneity and interests. Most of political parties have been also lack of conflict management losing ability to contain differences and retain internal solidarity. As a result, the clash of interests among cadres and elites has coloring parties' performance negatively affecting their political image widely covered by media then transferred to sympathizers (Gerber, Karlan, \& Bergan 2009). Parties' internal conflict is also predominantly caused by the weak of leadership and immaturity of the parties in democracy. That is proven by parties conducting an authoritarian party system in which the policy making process and the administrative system of political parties remains centralistic.

The National Awakening Party (PKB) is the clear example of this case. PKB is often called as 'the longest internal disputes party' emerging four chairs since 2004 causing political disorientation among voters (Kompas August 8 2008). PKB is one of the patron client parties giving its control on exalted figure namely the former President Abdurrahman Wahid or prominently known as Gus Dur turning the parties into personal property (Scott 1972). PKB has experienced a couple of internal rifts started by Matori Abdul Djalil's 'rebellion', followed by disputing congress in Semarang dividing it into two groups between Gus Dur-Muhaimin Iskandar and Alwi Shihab-Saifullah Yusuf (Gus Ipul). The congress unanimously elected Gus Dur as the chairman of PKB's powerful supervisory council (Dewan Syuro) and Muhaimin as the chairman of the party while Alwi-Gus Ipul rejected the election result on behalf of undemocratic mechanism. Because Gus Dur-Muhaimin was politically and legally stronger and acknowledged by government, Alwi-Gus Ipul then held a rival congress in Surabaya on May 28, 2005 that later gave a birth to the Ulema National Awakening Party (PKNU), which has subsequently hijacked a great number of PKB politicians (Jawa Pos 15 May 2005). The internal consolidation of the parties is no longer expected after the third wave of internal conflict emerged confronting between Gus Dur and his nephew Muhaimin Iskandar well-known as the current Minister of Work Force and Transmigration (2009-2014).

As a result, PKB has become the most fragile party among the established Islamic parties in recent years. Muhaimin could politically claim the years of internal conflicts would likely have no negative impact on the party's performance in the 2009 legislative election, because he is supported by 'politically anti-Gus Dur' ulemas and Nahdlatul Ulama (NU) institutionally. But the sanguine attitude seems to be misplaced since the NU's political endorsement would have no significant impact on the Nahdliyyin's political preferences again. It is widely perceived NU has greatly reduced its influence and authority as the nation's political moral guardian after internal schism and fragmentation separating the organization from the grassroots or Nahdliyyin.

The elites' politically profit oriented behaviors do not represent NU's values of Islamic populism led to the crisis of identity and value. NU politicians have tended to be a political commodity as the vote getters rather than as ideological strugglers (Umam 2006, Basewdan 2004, Feith 1951, Geertz 1965). As a logical consequence, NU tends to loss its credibility and respectable force to stand on its fundamental function of Islamic-pluralist civil society element. As a result, the PKB's solid support base among rural Javanese Muslims has significantly reduced in 2009 election in which it just achieved 5.2 percent after gaining 10 percent and 12 percent in the 2004 and 1999 election. PKB tended to be losing its golden era and facing a saturation point of an anti-climax trend of the electability.

An oligarchy of older politicians and the weak political leadership usually would hinder the internal reform and internal consolidation process of the parties. The PKB phenomenon is the example of political inclination towards a democracy deficit in which the elites tended to politicking traditionally and could not follow the steps towards a modern party. The lack of institutionalization of a democratic leadership mechanism in the party has become a political boomerang suffering itself. Thus, the high conflict intensity will considerably determine the level of political parties' immaturity potentially 
risking the trust of their supporters. If the seeds of conflict cannot be managed properly, it would be the time bomb collapsing the party. Since unmanaged internal clash of interests would consequently emerge 'political cannibalism' or ‘predatory confrontation' among elites and party cadres.

\section{The crisis of identity and the trend of political pragmatism}

One of the causes of Islamic parties shrinking electoral result is the trend of pragmatism abandoning the basic values of ideologies and identities in the political behavior (Fealy 2009, Baswedan 2004, Effendy 1998, Liddle \& Mujani 2007). What happened with PAN under Soetrisno Bachir leadership, who tried to change his own party's identity and characteristic, also happened in the Prosperous Justice Party (PKS). After gaining 600 percent increase of votes in 2004 election, PKS optimistically wanted to modernize its identity by transforming its ideological platform and movement character from 'Islamic centrist party' to be a more open party. What PKS did is strategically reasonable since, when the median voters are predominant in elections, the party needs to moderate their position to attract electors. In contrary, when the dominant voters are in the extreme position either left or right, the parties then should follow the trend by shifting itself in the extreme position also. As theoretically, the distribution of voters would influence how political parties position themselves (Dows 1957, Tanuwidjaja 2009).

In 2009 election, Indonesians are preserved to be median voters. To expand the captive market targeted 20 percent increase in 2009 election, PKS tried to metamorphose to be a middle party which is characteristically more friendly and pluralistic (Tempointeraktif 20 November 2005). Some attractive campaigns and advertisements had been created by easing the Islamic centrist ideological image. For example, it introduced the squeal of Merdeka (freedom) together with Allahu Akbar (Allah the great) for the state's independence ceremony advertisement. As a conservative Islamic party, PKS also released advertisement showing unveiled sympathizers which seems to be strange for Islamic values obliging to cover women's body (aurat). It also used the image of K.H. Hasyim Asyari and K.H. Ahmad Dahlan for its political campaign advertisement for attracting more Nahdliyyins which are well-known as the PKB's mass base as well as the Muhammadiyah cadres as the captive market of PAN and PMB. PKS also controversially nominated the former president and Indonesian dictator Soeharto as one of the national heroes to attract voters yearning for the New Order's successes. The political behavior has encouraged the bad impression negatively impacting its political images as a clean, idealist and professional party before the sympathizers.

Beside that, $\mathrm{PKS}$ ' functionaries also seem to be more pragmatic to seek political advantage reducing its religious or Islamic image and making PKS lose its distinction. As a result, the PKS' moderation agenda results a new dilemma either getting new supporters or losing its traditional supporters lately considering it just like other ordinary pragmatic parties. PKS' pragmatic behavior using double standard political strategy before the government and the opposition during 2004-2009 is also another fact of political pragmatism and opportunism making a bad impression of 'political hypocrisy'. The experiences of interpellation right usage for Iran embargo case (2007), Lapindo case (2008), BLBI case (2009), imported-rice case (2006-2007), mall-nutrition case (2005) mostly ending with 'anticlimax' was the clear fact of the pragmatism. As the government supporters and a part of policy makers, PKS had intensively attacked executive policies to attract public attention and to depict itself as the hero and protector of people's interests.

On the other hand, almost the oppositional movements suddenly stopped and 180 degrees changed its decision and political behavior after the discussion of compensation with the government element. Uniquely, that was not only conducted by PKS, but also by all Islamic parties in the parliamentary body during 2004-2009 including PPP, PAN, PKB, PBB and PBR. Thus, it is not surprising when the Islamic parties could not keep up its momentum to significantly raise the electability in 2009 election otherwise getting relatively stagnant or dramatically decline of the votes. Those are a huge price should be paid by Islamic parties for its lack of identity and pragmatism hurting its reform credentials and perceived idealism, making voters more skeptical and reluctant. 


\section{The Power and strategy of Islamic parties towards 2014 election}

During the second-half Yudhoyono's administration (2009-2014), Islamic parties seem to be unable to deal with the three fundamental problems above. The Islamic political parties did not pay more attention to the social welfare issue. When the people are waiting for public policy changes related to their real everyday needs, the Islamic parties indeed dissolve in the high level politics which does not touch the grassroots everyday life. The Islamic parties seem to be trapped within the major parties' political games. People will see them as not much different with the other ordinary secular political parties. Meanwhile factionalism and internal conflict are still coloring most of the Islamic parties' internal political dynamics.

In the recent political configuration, all Islamic political parties also decided to join into a progovernment coalition. Despite their pledge to support the government, the political parties do not allow the President to control them through a permanent coalition. As a result, the government has been powerless in coping with the House's political attacks due to the fragile coalition set up to support President Yudhoyono's government. The coalition should have protected the government's policies from opposition. Unfortunately, as has been long recognized, the character of a coalition in the Indonesian political context is always liquid, temporary and strongly influenced by short-term interests.

As a result, the ruling political party has never managed to secure the loyalty of all its allies, leading to repeated infighting within the coalition. That is an anomaly of presidential system which should provide a secure and stable executive position and a legitimate president (Lijphart 1992:11-15, Mainwaring \& Shugart 1998:144, Sulistiyanto 2004:7). The weak presidential system has been continued in 2009-2014 government period after the permanent coalition format has been failed to set up. The situation provides two political possibilities for Islamic parties. Firstly, by being accommodated into the government body a semi-permanent coalition concept, Islamic political parties will get more energy to revitalize and restructuring caderization and political strategies, to improve the prospects of these parties. But, the Islamic parties also will face political distrust from the people due to its pragmatic and opportunistic political behavior. Moreover, theoretically, under a strong presidential system, the possibility of the coalition members doing political maneuvers would be unacceptable. The members of the coalition would be docile parties totally supporting the government's policies. It means that, secondly, by joining into government, the Islamic parties's movements are more limited and shadowed by the ruling party as the major sponsor of the coalition. It means that the good and bad image of the Islamic parties will be determined by the successful or failed government.

The situation needs an opportunistic political strategy rather than moralist political behavior in order to maintain both critical position within government and the erosion of electability. The concept of "siyasat al-akhlaq" or a moralist politics as proposed by philosopher and theologian al-Ghazali (10581111) becomes irrelevant within the pragmatic political constellation. Thus, public considers the Islamic political parties' behavior is merely same with the ordinary secular parties. That is why the recent research conducted by Saiful Mujani, R. William Liddle and Kuskrido Ambardi (2012) explained that Indonesian political behavior found that religion has not had a crucial role in the three general elections of Indonesia's reformation era. Some Islamic-based political parties have transformed themselves from the first class political party to be a mediocre political player compared to the nationalist and secularist parties.

To deal with the situation, some strategic changes must be done to save their existence. When the shrinking trend is inevitable, the only way that unpopular Muslim parties could succeed in the 2014 elections is to form a single coalition to become solid and more powerful political forces. Another way to do is looking for a new common leader in the Presidential election that could put aside partisan differences, with the new vision, and be able to attract public to vote him or her to be the symbol of Islamic parties' collectivity to create solution for the better of Indonesia. 


\section{Conclusion}

Despite the shrinking trend, the Islamic political parties will continue to be crucial players in the Indonesian political stage. Their position within government has provided some possibilities. The opportunity to join with government body would make Islamic parties more effective to revitalize their powers by intensifying cadres' consolidation, restructuring the political communication strategy and widening political networks across various ideological and religious streams. But, they are also potentially be subordinated and systematically weakened by the ruling party when the government being successful to set up good governance in the country. Thus what Islamic parties need to secure their power and electability in 2014 is a communication skill to effectively socialize their significant roles behind the government's success or failed policies. The future of Islamic parties also will be determined by their strategies to deal with three pivotal problems mentioned above such as the identity crisis to avoid the pragmatism, factionalism or internal conflict, the weak leadership, and inability to transform identities and ideologies into political platforms and real program touching people. If during the next two years towards 2014 elections the Islamic parties could learned well from their bitter experiences in 2009 election by principally repairing their conflict management, shifting political platform and programs based on their ideologies, and trying to conduct healthy politicking without narrow pragmatism, the 2014 political constellation will be more strongly influenced by Islamic political parties' roles.

\section{References}

Anderson B (1983) Imagined Communities: Reflections on the Origin and Spread of Nationalism. Revised and extended, 1991. London: Verso Books.

Arakaki RK (2008) 2008 Malaysian election: the end of Malaysia's ethnic nationalism? Asian Politics and Policy 1 (1):79-96.

Baswedan A (2009) Circulation of Votes in the 2004 election, unpublished.

Benz M \& Stutzer A (2004) Are voters better informed when they have a larger say in politics? Public Choice 119:31-59. Boland BJ (1971) The Struggle of Islam in Modern Indonesia, The Hague: Martinus Nijhoff.

Bowler S \& Donovan T (2002) Democracy, institutions, and attitudes about citizen influence on government. British Journal of Political Science 32:371-390.

Crouch H (1969) The Army and the Politics in Indonesia. Ithaca and London: Cornell University Press.

Crouch H (1978) The Army and Politics in Indonesia. Ithaca and London: Cornell University Press.

Donovan T, Tolbert CJ, \& Smith DA (2009) Political engagement, mobilization, and direct democracy. Public Opinion Quarterly 73 (1):98-118.

Downs A (1957) An economic theory of democracy, New York, Harper in Tanuwidjaja, Sunny, Did you vote for religious conservatism? The Jakarta Post, 23 April 2009.

Effendy B (1998) Islam dan Negara: Transformasi Pemikiran dan Praktik Politik Islam di Indonesia. Jakarta: Paramadina.

Effendy B (2003) Islam and the State in Indonesia. Singapore: Institute of Southeast Asian Studies.

Elson RE (2002) In Fear of the People: Suharto and the Justification of State-sponsored Violence Under the New Order. In Roots of Violence in Indonesia, Freek Colombijn \& J. Thomas Lindbad (ed). Leiden: KITLV Press.

Emmerson D (1976) Indonesia's Elite: Political Culture and Cultural Politics. Ithaca: Cornell University Press.

Fealy G (2009) Indonesia's Islamic Parties in Decline. Inside Story, 11 May.

Fealy G \& White S (ed) (2008) Expressing Islam: Religious Life and Politics in Indonesia. Indonesia Update Series, RSPAS, Australian National University.

Feith H (1962) The Decline of Constitutional Democracy in Indonesia. Ithaca: Cornell University Press.

Feith H (1951) The Indonesian Elections of 1955. Southeast Asia Program: Cornell University. 
Geertz C (1960) The Religion of Java. Chicago and London: University of Chicago Press.

Geertz C (1965) The Social History of an Indonesian Town. Cambridge: MIT.

Gellner, E (1983) Nations and Nationalism. New Perspectives on the Pasts Series. In: RI Moore. Fifth printing, 1993. Ithaca, New York: Cornell University Press.

Gerber AS, Karlan D, \& Bergan D (2009) Does the media matter? A field experiment measuring the effect of newspapers on voting behavior and political opinions. American Economic Journal: Applied Economics 1(2):35-52.

Hamayotsu K (2009) Does Piety Matter? Islamist Party Mobilization in Muslim Southeast Asia. Working paper, Department of Political Science: Northern Illinois University.

Jackson KD (1980) Traditional Authority, Islam, and Rebellion: A Study of Indonesian Political Behavior. Berkeley: University of California Press.

King D (2003) Half Hearted Reform: Electoral Institutions and the Struggle for Democracy in Indonesia. Westport: Praeger.

Kinder D \& Kiewiet D (1981) Sociotropic politics. British Journal of Political Science 1:129-161.

Kompas (2008) PKB, Partai dengan Konflik Terlama di Dunia. Kompas, 8 August 2008. http://www.kompas.com/read/xml/2008/08/08/1518535/pkb.partai.dengan.konflik.terlama.di. dunia.

Kompas (2009) Luluhnya Dominasi Politik Desa. Kompas, 1 April 2009. http://nasional.kompas.com/read/xml/2009/04/01/09164599/luluhnya.dominasi.politik.di.desa

Lassen D (2005) The effect of information on voter turnout: evidence from a natural experiment. American Journal of Political Science 49:103-118.

Lev D (1967) Political Parties in Indonesia. Journal of Southeast Asian History. Special issue, March.

Liddle RW (1970) Ethnicity, Party, and National Integration: An Indonesian Case Study. New Haven: Yale University Press.

Liddle RW \& Mujani S (2007) Islamist Parties and Democracy: The Indonesian Case. Working paper: Ohio State University.

Lijphart A (ed) (1992) Parliamentary Versus Presidential Government. Oxford: Oxford University Press.

Maarif ASyafi'i (1988) Islam dan Politik di Indonesia pada Masa Demokrasi Terpimpin (1959-1965), Yogyakarta: IAIN Sunan Kalijaga Press.

Mainwaring S \& Shugart MS (1998) Juan Linz, Presidentialism, and Democracy: A Critical Appraisal. In: Scott Mainwaring \& Arturo Valenzuela (eds). Politics, Society, and Democracy: Latin Americ. Baltimore, Maryland, the John Hopkins University Press.

Mandelsohn M \& Cutler F (2000) The Effect of referenda on democratic citizens: information, politization, efficacy and tolerance. British Journal of Political Science 30:669-698.

Mann M (1986) The sources of social power: A History of Power from the Beginning to A.D. 1760 Vol. 1. New York: Cambridge University Press.

Misra A (2003) Rise of religious parties in Pakistan: causes and prospects. Strategic Analysis 27(2):186-215.

Noor F (2003) Blood, sweat and jihad: The radicalization of the political discourse of the PanMalaysian Islamic Party (PAS) from 1982 onwards. Contemporary Southeast Asia 25(2):200232.

Nurbaiti A (2009) To Veil, or Not to Veil, and the Political Clothes Hanger. The Jakarta Post, 29 May 2009.

Öniş Z (2006) Globalization and Party Transformation: Turkey's Justice and Development Party in Perspective. In: Burnell P (ed). Globalizing Democracy: Party Politics in Emerging Democracies. London: Routledge.

Pepinsky TB, Liddle WR, \& Mujani S (2009) Testing Political Islam's Economic Advantage: The Case of Indonesia. unpublished, 23 March. http://www.lsi.or.id/riset/91/Testing\%20Political\%20Islam\%E2\%80\%99s\%20Economic\%20 Advantage:\%20The\%20Case\%20 of\%20Indonesia.

PKS: Istri SBY Lebih Cantik Berjilbab (2009) [Accessed 27 May]. http://www.pksejahtera.org/v2/index.php?op=isi\&id=7423. 
Ricklef MC (2008) Religion, Politics, and Social Dynamic in Java: Historical and Contemporary Rhymes. In: Fealy, Greg \& White S (ed). Expressing Islam: Religious Life and Politics in Indonesia. Indonesia: Update Series, RSPAS, Australian National University.

Roy O (1994) The Failure of Political Islam. New York: Harvard University Press.

Samson A (1978) Conception of Politics, Power, and Ideology in Contemporary Indonesian Islam. In: Jackson KD \& Pye LW (eds). Political Power and Communication in Indonesia. Berkeley, Los Angeles, London: University of California Press.

Scott JC (1972) Patron-client politics and political change in Southeast Asia. The American Political Science Review 66(1):91-113.

Smith D \& Tolbert C (2004) Educated by Initiative: The Effects of Direct Democracy on Citizens and Political Organizations in the American States. Ann Arbor: University of Michigan Press.

Smith MA (2002) Ballot initiatives and the democratic citizen. Journal of Politics 64:892-903.

Sulistiyanto P (2004) The 2004 General elections and the virtues of Indonesian presidentialism. Philippine Journal of Third World Studies 19(2):4-24.

Umam AK (2006) Kiai \& Budaya Korupsi di Indonesia. Semarang: Rasail.

van Dijk C (1981) Rebellion Under the Banner of Islam: The Darul Islam in Indonesia. The Hague: M. Nijhoff.

Ward KE (1970) The Foundation of the Partai Muslimin Indonesia. Ithaca, Modern Indonesian Project, Southeast Asia Program: Cornell University.

Xinhua (2008) Survey: Economic Issue Tops Indonesian. Election agenda in 7 February 2009. 